FELIPE JIM OMORI

\title{
FORMA JURÍDICA E TRIBUTAÇÃO
}

Dissertação de Mestrado

Orientador: Professor Associado Dr. Paulo Ayres Barreto

UNIVERSIDADE DE SÃO PAULO

FACULDADE DE DIREITO

São Paulo - SP

2018 
FELIPE JIM OMORI

\title{
FORMA JURÍDICA E TRIBUTAÇÃO
}

\begin{abstract}
Dissertação apresentada à Banca Examinadora do Programa de PósGraduação em Direito, da Faculdade de Direito da Universidade de São Paulo, como exigência parcial para obtenção do título de Mestre em Direito, na área de concentração de Direito Econômico, Financeiro e Tributário, sob orientação do Prof. Associado Dr. Paulo Ayres Barreto.
\end{abstract}

\section{UNIVERSIDADE DE SÃO PAULO}

FACULDADE DE DIREITO

São Paulo - SP

2018 
Omori, Felipe Jim

Forma Jurídica e Tributação / Felipe Jim Omori; orientador Paulo Ayres Barreto -- São Paulo, 2018.

235

Dissertação (Mestrado - Programa de Pós-Graduação em Direito Direito Econômico, Financeiro e Tributário) - Faculdade de Direito, Universidade de São Paulo, 2018.

1. Direito Tributário. 2. Forma Jurídica. 3. Negócio Jurídico. 4. Lançamento Tributário. I. Barreto, Paulo Ayres, orient. II. Forma Jurídica e Tributação. 
Nome: OMORI, Felipe Jim

Título: Forma jurídica e tributação

Dissertação apresentada à Banca Examinadora do Programa de Pós-Graduação em Direito, da Faculdade de Direito da Universidade de São Paulo, como exigência parcial para obtenção do título de Mestre em Direito, na área de concentração de Direito Econômico, Financeiro e Tributário, sob orientação do Prof. Associado Dr. Paulo Ayres Barreto.

Aprovado em:

Banca Examinadora

Prof.(a) Dr.(a)

Instituição:

Julgamento:

Prof.(a) Dr.(a)

Instituição:

Julgamento:

Prof.(a) Dr.(a)

Instituição:

Julgamento: 
Ao professor Paulo Ayres Barreto pela orientação e dedicação no exercício do magistério.

À minha família pelo suporte e base necessária para superar os desafios da vida. À memória de minha mãe, cuja partida deixou o mundo mais cinza. À Laura, pelo amor e apoio incondicional, que a cada dia me ajudam a enxergar novamente as cores da vida. 


\section{RESUMO}

OMORI, Felipe Jim. Forma Jurídica e Tributação. Dissertação de Mestrado - Faculdade de Direito, Universidade de São Paulo, São Paulo - SP, 2018.

O presente trabalho possui o objetivo de estudar e analisar o fenômeno da incidência da norma tributária e a sua relação com a forma jurídica de determinado negócio, cujos efeitos estejam submetidos à tributação. Pretendemos analisar a própria forma jurídica, seu conceito e sua função, especialmente a partir de sua relação com outros institutos, como a tipicidade contratual e a causa dos negócios jurídicos. A partir destes institutos cuja origem está no Direito Civil, faremos também uma análise da inter-relação entre este ramo do Direito e o Direito Tributário, para compreender a importância da forma e os efeitos que ela pode produzir neste último. De rigor será, também, a análise de situações limiares na tributação, como a elisão, a teoria da interpretação econômica do fato gerador, o propósito negocial, simulação e abuso de direito, para identificar, nestas situações, se é possível definir qual o verdadeiro objeto e limite da tributação e qual o papel da forma jurídica na atividade do lançamento tributário.

Palavras-chave

Forma jurídica. Tributação. Negócio Jurídico. Substância. Causa. Propósito negocial. Interpretação. Elisão. Lançamento. 


\begin{abstract}
OMORI, Felipe Jim. Legal Form and Taxation. Master's Degree - Faculdade de Direito, Universidade de São Paulo, São Paulo - SP, 2018.

The present dissertation aims the study and analysis of the phenomenon of the incidence of a tax norm and its relationship with the legal form of a certain juristic act, subject to taxation. We intend to analyze the institute of the legal form, its concept and function, especially from its relationship with other legal institutes, such as the contractual standards and the cause of the juristic acts. From those Civil Law's institutes, an analysis of the interrelationship between such field of the Law and the Tax Law should be necessary to comprehend the importance of legal form and its effects in the Tax Law. In this sense, an analysis of extreme situations involving taxation, such as tax avoidance, economic interpretation of the triggering event, business purpose, simulation and abuse of rights, will also be necessary to identify, from these situations, if it is possible to define the real object and limit of taxation and the role of the legal form in the tax assessment activity.
\end{abstract}

Key words

Legal form. Taxation. Juristic act. Substance. Cause. Business purpose. Interpretation. Tax avoidance. Tax assessment. 


\section{ÍNDICE}

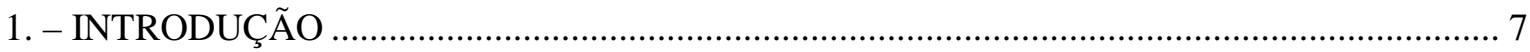

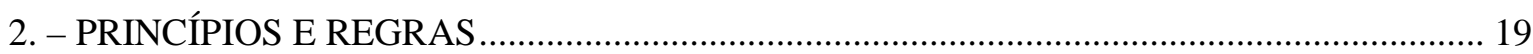

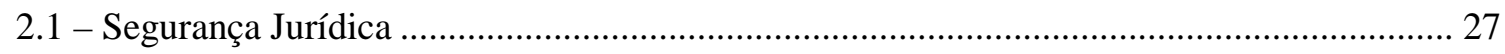

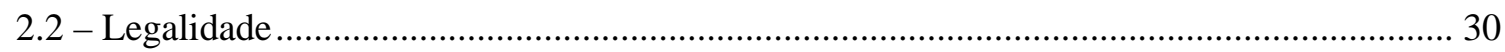

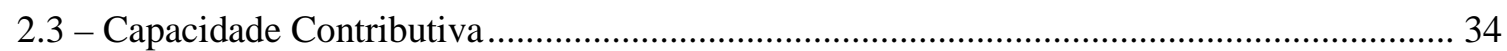

3. - COMPETÊNCIA TRIBUTÁRIA E CONCEITOS CONSTITUCIONAIS ................................. 45

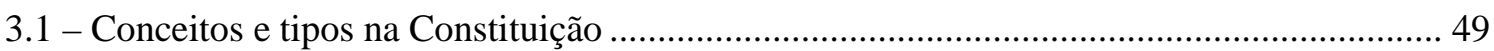

4. - DIREITO TRIBUTÁRIO E DIREITO CIVIL - INFLUÊNCIA E EFEITOS ............................ 65

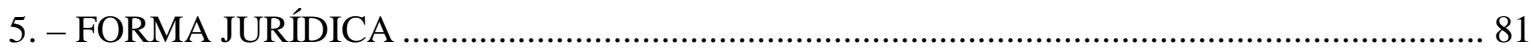

5.1 - Acepções do termo "forma jurídica" - delimitação do objeto do estudo............................... 81

5.2 - Forma como requisito constitutivo do negócio jurídico - "forma-formalidade" ................. 85

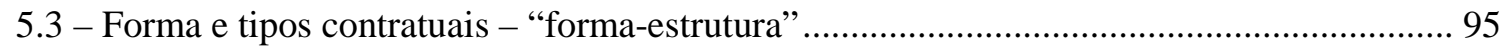

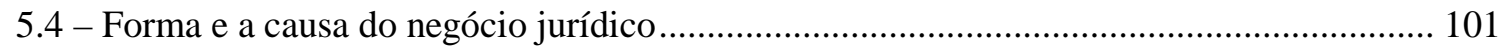

6. - CONTORNOS DA FORMA E SUA RELAÇÃO COM A SUBSTÂNCIA ............................ 113

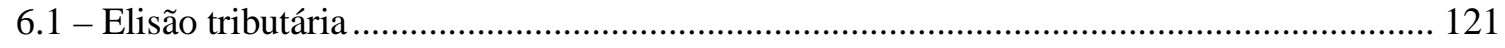

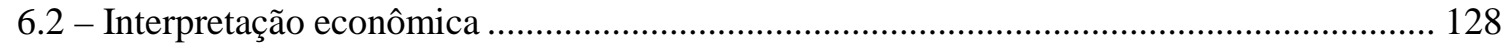

6.3 - Propósito negocial - business purpose test ....................................................................... 142

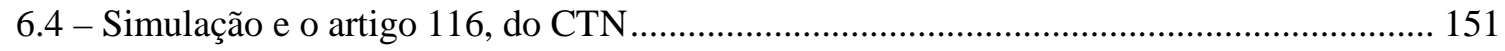

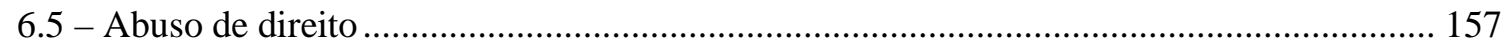

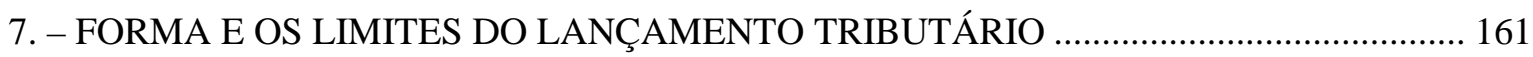

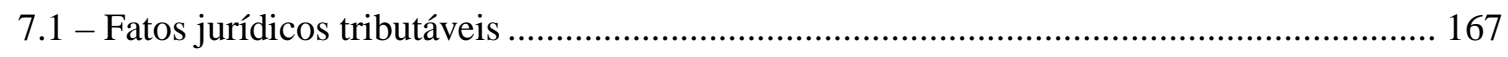

7.2 - Capacidade contributiva e legalidade e sua força normativa ............................................ 180

7.3 - Alternativas postas pela legislação ao contribuinte............................................................ 185

7.4 - Conjugação entre forma, causa e substância....................................................................... 188

7.5 - Breve comentário acerca dos efeitos práticos do presente estudo....................................... 204

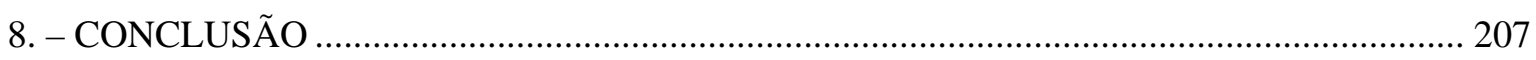

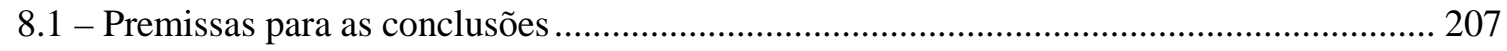

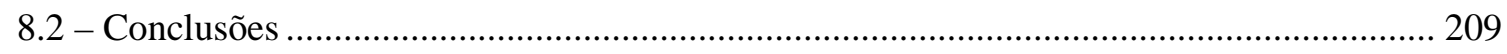

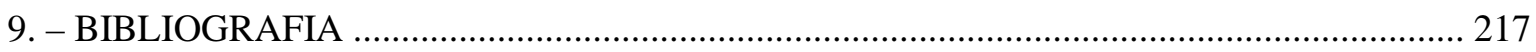




\section{1. - INTRODUÇÃO}

O que é a forma de um negócio jurídico e qual a sua relevância para o Direito Tributário? Estas serão as questões que buscaremos analisar no presente trabalho.

A definição da tributação aplicável a um determinado negócio jurídico é tarefa muitas vezes complexas no Brasil, que conta com uma extensa legislação tributária e normas que constantemente desafiam a capacidade interpretativa dos contribuintes.

Apesar de a legislação ser muitas vezes detalhista e minuciosa, outras tantas vezes é ela ambígua ou incompleta, sem atender a um rigor legislativo que permita uma clara conclusão por parte do intérprete.

Disto verificamos diversas discussões relativas a temas fundamentais do Direito Tributário, como a da própria definição da tributação aplicável a um negócio jurídico, quando o Fisco e o contribuinte chegam a conclusões diametralmente distintas, tão grande é a complexidade e incompletude da legislação tributária.

O nosso tema de estudo, assim, está relacionado com um dos aspectos inerentes a tais discussões que hoje abundam no contencioso judicial e administrativo de nosso país.

Pretendemos analisar, assim, a importância da forma jurídica de um negócio firmado pelas partes e qual a extensão de seus efeitos na definição da tributação aplicável a tal negócio.

O termo "forma jurídica" ao qual nos referimos, porém, será aqui tratado em duas acepções distintas, mas igualmente relevantes na análise da tributação aplicável a um negócio jurídico.

A primeira acepção do termo é a relativa às formalidades exigidas pelo ordenamento para que um negócio jurídico seja considerado existente e também para que seja considerado válido. Chamaremos esta acepção de "forma-formalidade".

A segunda acepção do termo é que associa forma à categoria jurídica contratual de determinado negócio. Isto é, está relacionada com a tipificação de negócios jurídicos pelo ordenamento e a criação de categorias jurídicas próprias para cada negócio, com efeitos jurídicos definidos pela legislação. Trataremos esta acepção pelo termo "formaestrutura".

Muito se discute atualmente na doutrina brasileira acerca da possibilidade de aplicação em nosso Sistema da interpretação de fatos jurídicos que dê prevalência à 
substância em detrimento da forma adotada pelo contribuinte, sem uma justificativa fundamentada para sua desconsideração. Dá-se muita relevância para sustentar a importância da substância, mas não para se justificar a desconsideração da forma, enquanto elemento jurídico que, como veremos, é intrínseco à própria constituição do negócio jurídico e possui importância e função determinada no ordenamento.

Isto é, muitas vezes, acaba-se por desconsiderar a forma com base em argumentos que deem relevância e importância à substância, sem, contudo, explicitar os fundamentos que autorizariam a desconsideração pura e simples da forma.

Nosso objetivo, portanto, será o de analisar qual a relevância da forma jurídica para o Direito Tributário na determinação da tributação aplicável a determinado negócio jurídico.

Em uma analogia simples, pensemos em um edifício, que possua em seu último andar um mirante. Para chegar a tal mirante, há uma escada e um elevador.

Em uma primeira situação, cobra-se um valor apenas das pessoas que queiram utilizar o elevador para chegar ao mirante, sendo a escada de livre utilização.

Em uma segunda situação, nada se cobra na subida, mas se cobra quando da chegada ao topo do prédio, independentemente do meio utilizado.

E, em uma terceira situação, no topo do edifício há uma área de observação livre na qual nada se cobra na subida, e outra área com um restaurante, na qual também não há cobrança para a subida, mas há cobrança para desfrutar dos serviços deste estabelecimento.

Analisando esta analogia, temos que a primeira situação equivaleria à conclusão de que o ordenamento jurídico almeja tributar uma forma jurídica, independentemente de seus efeitos jurídicos ou econômicos, isto é, cobrou-se apenas pelo uso do elevador, independentemente do fato de que os dois meios levarão as pessoas ao mesmo local.

A segunda situação equivaleria ao ordenamento determinar a tributação dos efeitos jurídicos de um determinado negócio, isto é, chegar ao topo do edifício, não importando a forma como lá se chegou - se pelo elevador, ou se pela escada.

Por fim, a terceira situação equivale a objetivar a tributação apenas aos efeitos jurídicos de uma atividade, não importando a forma, ou os efeitos jurídicos. Tributa-se um determinado proveito ou situação jurídica específica, independentemente da forma, ou da posição jurídica do contribuinte, que poderia, por exemplo, ter ficado na área gratuita, mas 
pretendeu um efeito específico com sua subida, no exemplo citado, uma refeição no restaurante.

A analogia pode parecer simplista, mas serve para demonstrar quais as diferentes facetas que pretenderemos analisar acerca da tributação. Esta analogia poderia ainda ser complementada com outras situações, que também pretendemos explorar neste trabalho.

A exemplo, poderíamos supor que, na segunda situação, apesar da cobrança no topo do edifício, os que subiram de escada teriam um desconto no valor cobrado, o que nos levaria a uma situação na qual a forma (escada), conjugada com um determinado efeito jurídico (chegar ao topo), implicaria uma tributação ou cobrança menor.

Toda análise científica do Direito encontra dificuldades no fato de que ele é uma linguagem (metalinguagem). E por ser uma linguagem, muitas vezes vem carregado de uma imprecisão conceitual ou multiplicidade de significados a depender do termo utilizado ou contexto no qual ele é empregado. Hans Kelsen ${ }^{1}$ em sua Teoria Pura do Direito apontava que o ordenamento comporta diversas formas de indeterminação conceitual, sejam elas no ato de aplicação do Direito, intencionais do legislador ou não intencionais.

Nesse sentido, como bem aponta Tárek Moysés Moussallem², o Direito é formado por atos de fala. É o uso da linguagem para criar normas, que farão referência sempre aos demais atos de fala constante do mesmo universo. Cita o autor que uma promessa na acepção comum não se iguala ao mesmo termo usado pelo direito positivo, assim como uma advertência, que pode ser entendida na linhagem usual com um efeito ilocucionário, no direito positivo tem o efeito de "constituir em mora", por exemplo.

É importante ter em mente, porém, que as referências feitas pelo ordenamento, ainda que imprecisas ou indeterminadas, buscam sempre um instituto ou um conceito também jurídico e não, simplesmente, acontecimentos do mundo real, não captados pelo Direito.

Por este motivo, nosso estudo estará baseado na premissa de que o ordenamento jurídico sempre se vale de elementos constantes do mesmo sistema, isto é, o Direito. Tendo isto em mente, pretendemos conjugar lições de diferentes linhas doutrinárias e sobre diferentes institutos e temas de Direito Tributário (e também do

\footnotetext{
${ }^{1}$ KELSEN, Hans. Teoria Pura do Direito, tradução de João Bapstista Machado. São Paulo: Martins Fontes, 2006. Pgs. 388/391.

${ }^{2}$ MOUSSALLEM, Tárek Moysés, Revogação em Matéria Tributária, $2^{\mathrm{a}}$ edição. São Paulo: Noeses, 2011. Pgs. 65 e 78.
} 
Direito Civil) que possam contribuir com a análise acerca do papel da forma jurídica na tributação.

A sistemática de estudo que adotaremos no presente trabalho, assim, consistirá em uma análise inicial de alguns institutos básicos do Direito Tributário, que conformam a atividade do intérprete e do aplicador do Direito, bem como da análise de conceitos e institutos de Direito Civil relativos à forma jurídica (em ambas as acepções), conjugando todas estas observações em situações em que a forma jurídica se mostra desafiada ou desconsiderada.

O primeiro capítulo, assim, será dedicado à análise dos princípios e regras constitucionais e a identificação da natureza destas diferentes espécies normativas que conformam e delimitam a atividade tributária do Estado.

Analisaremos, assim, os institutos da segurança jurídica, da legalidade e da capacidade contributiva, que, a nosso ver, são relevantes para o estudo que pretendemos desenvolver. Pretendemos verificar, assim, se estes institutos de manifestam no nosso ordenamento enquanto princípios ou enquanto regra - ou ambos - para delimitarmos a sua força normativa.

Esta análise é importante, como veremos ao longo do trabalho, pelo fato de que muitas vezes a tributação no Brasil é definida a partir da invocação de princípios constitucionais, havendo possibilidade de interpretação tanto no sentido de que tais princípios trariam uma maior elasticidade ao poder de tributar, quando no sentido de que eles, em verdade, limitariam a atuação do Estado. Em paralelo, a existência de regras constitucionais igualmente é relevante para nosso estudo, pois elas também conformam e delimitam a atuação do Estado ou condicionam a atividade do próprio intérprete.

Na parte final de nosso trabalho, as premissas estabelecidas acerca da dinâmica entre regras e princípios serão valiosas para estabelecermos em que medida a forma jurídica pode ser desconsiderada ou seria irrelevante na aplicação da norma tributária.

O Capítulo 2 será dedicado também a um tema fundamental em qualquer análise do Direito Tributário em que se pretenda definir ou estabelecer os limites e contornos da tributação. O estudo da distribuição competências tributárias é relevante para entendermos qual o real objeto da tributação no Brasil e de que maneira a existência de disciplina constitucional sobre o assunto é relevante para a definição da tributação aplicável a um determinado negócio jurídico. 
É pela análise da distribuição de competências tributária e pela verificação do uso pela Constituição de conceitos jurídicos para fins de determinação destas competências que verificaremos se a forma jurídica foi ou é elemento relevante na definição da tributação, ou se o tratamento constitucional hoje existente simplesmente desconsidera as formas jurídicas dos negócios realizados pelos contribuintes, para fins de aplicação da tributação.

Nesse sentido, traremos considerações da doutrina sobre o tema, bem como analisaremos de forma crítica a jurisprudência do Supremo Tribunal Federal - STF mais recente sobre a existência ou não de conceitos constitucionais na delimitação de competências tributárias dos Entes Federados.

O Capítulo 4 de nosso estudo também tratará de premissa para o nosso trabalho, relativa à inter-relação do Direito Tributário e Direito Civil. Com efeito, a forma jurídica é instituto eminentemente de Direito Civil, assim como é a disciplina dos atos jurídicos de forma geral.

Será importante, assim, analisarmos em que medida as disposições do Direito Civil influenciam ou condicionam a aplicação da Lei tributária e a determinação da tributação de um negócio jurídico.

Nesta análise também verificaremos quais os efeitos das alterações legislativas de natureza Civil na própria definição das competências tributárias estabelecidas pela Constituição, em complementação à análise realizada no Capítulo 3 mencionado acima.

Definidas as premissas nestes capítulos iniciais, o Capítulo 5 iniciará a análise do tema objeto de nosso estudo.

Neste item, analisaremos o instituto da forma jurídica, nas duas acepções mencionadas acima - forma-formalidade e forma-estrutura -, delimitando, assim, o objeto de estudo.

Acerca da forma-formalidade, Antônio Junqueira de Azevedo ${ }^{3}$, catedrático da Faculdade de Direito da Universidade de São Paulo, afirmava que "não há negócio sem forma”, esclarecendo que a forma de um negócio jurídico é o meio pelo qual o indivíduo expressa sua vontade. Esta forma pode se dar das mais diversas maneiras, de acordo com o que for autorizado e aceito pelo Direito, podendo ser oral, escrita, tácita, ou, ainda, pela omissão ${ }^{4}$.

\footnotetext{
${ }^{3}$ AZEVEDO, Antônio Junqueira de. Negócio Jurídico, Existência, Validade e Eficácia. São Paulo: Saraiva, 2002. Pg. 126.

${ }^{4}$ Idem.
} 
Além de próprio elemento de existência do negócio jurídico, a forma também é meio de verificação de sua validade, quando o ordenamento exigir seja ela determinada para sua prática.

Mesmo negócios que não possuam forma prescrita, isto é, negócios de forma livre (atípicos), devem atender a determinados requisitos para que sejam considerados formalizados e, portanto, existentes ${ }^{5}$. Não possuir forma prescrita em lei, portanto, não equivale a prescindir de forma.

A importância da forma-formalidade no nosso Direito é inegável, enquanto expressão linguística da vontade.

Como bem ressalta Heleno Taveira Tôrres ${ }^{6}$, tal relevância possui origens remotas, podendo ser verificada, inclusive, na Lei das Doze Tábuas, a qual já estabelecia que aquilo que a língua exprimisse se tornava Direito ${ }^{7}$.

O mesmo professor ${ }^{8}$ ainda ensina:

\begin{abstract}
Normas sobre formas dispõem especialmente sobre reconhecimento de validade de outras normas, dirigem-se à conduta das fontes qualificadas de produção de normas, estabelecendo como estas devem agir na construção de normas jurídicas. Por isso, têm um sobrevalor que não as torna mera exceção a uma regra de validade, que, esta sim, é uma norma geral sobranceira, fundante de todo o sistema.
\end{abstract}

$\mathrm{O}$ atual desenvolvimento econômico de nossa sociedade e o aumento na complexidade das relações comerciais, que muitas vezes alcançam extensões mundiais, tornam realidade a existência de negócios cada vez mais abrangentes, firmados para regular um número cada vez maior de atividades e desafiam, inclusive, a doutrina tradicional acerca da classificação dos contratos ${ }^{9}$.

O direito brasileiro concede grande (ainda que relativa) autonomia contratual às partes, facultando-lhes adotar contratos já previstos na legislação (os chamados

\footnotetext{
5 JUNQUEIRA, op. cit., 2002. Pg. 126.

${ }^{6}$ TÔRRES, Heleno Taveira. Direito Tributário e Direito Privado: Autonomia Privada, Simulação, Elusão Tributária. São Paulo: Revista dos Tribunais, 2003. Pg. 121

7 Conforme menciona o autor, a Tábua VI estabelecia: “cum nexum faciet mancipiunque, uti língua nuncupassit ita ius esto". Em tradução livre: "Quando alguém faz um juramento, contrato ou venda, anunciando isso oralmente em público, deverá cumprir sua promessa".

${ }^{8}$ Ibidem. Pg. 149.

${ }^{9}$ KATAOKA, Eduardo Takemi. A Coligação Contratual. Rio de Janeiro: Editora Lumen Juris, 2008. Pgs. 43/54.
} 
contratos típicos), ou mesmo firmando contratos por ela não regulamentados (contratos atípicos) ${ }^{10}$, todos eles que ainda podem guardar relações de vínculo ou coligação (seja necessária, seja voluntária) entre $\mathrm{si}^{11}$, formando, virtualmente, um universo infindável de possibilidades negociais.

É de total liberdade do particular submeter parte de sua esfera jurídica de interesse em acordo com outro particular, desde que não tenha como objeto um ilícito e desde que observe a função social de tal negócio jurídico ${ }^{12}$.

Havendo autorização legislativa que concede grande autonomia aos particulares na elaboração de negócios jurídicos - como se pode defluir da atual disciplina sobre o tema trazida pelo Código Civil em vigor ${ }^{13}$-, são inúmeras as combinações de dados e situações que podem surgir e que deverão ser analisadas pelo aplicador do Direito Tributário.

Além deste fator jurídico, há também o fator social, qual seja, o constante desenvolvimento econômico e o surgimento de atividades e produtos novos a cada dia, exigindo, da teoria contratual civil, uma constante adaptação ${ }^{14}$.

Também o intérprete do Direito Tributário deve acompanhar esta evolução, garantindo sempre a correta aplicação da legislação constitucional e infraconstitucional, a fim de garantir a exigência tributária justa (isto é, nos limites do que a lei determina).

Dada a multiplicidade de formas admitidas pelo Direito, é importante analisar qual a sua relevância na identificação do próprio negócio jurídico e se este papel desempenhado pela forma possui impacto na aplicação da norma tributária.

Como bem ressalta Antônio Junqueira ${ }^{15}$, "o negócio não é o que o agente quer, mas sim o que a sociedade vê como declaração de vontade do agente”. E é a partir da necessidade de regramento dos negócios jurídicos mais usuais em determinada sociedade que o ordenamento passa a disciplinar determinadas categorias negociais, tipificando os contratos e dando origem ao que nos referimos neste trabalho como forma-estrutura.

\footnotetext{
${ }^{10}$ O Código Civil (Lei $\mathrm{n}^{\mathrm{o}}$ 10.406, de 10 de janeiro de 2002) atualmente em vigor, em seu artigo 425 estabelece que "é lícito às partes estipular contratos atípicos" (observadas as normas gerais fixadas no Código).

${ }^{11}$ MARINO, Francisco Paulo De Crescenzo. Contratos Coligados no Direito Brasileiro, $1^{\mathrm{a}}$ Edição, $2^{\mathrm{a}}$ Tiragem. São Paulo: Saraiva, 2009. Passim.

12 VERÇOSA, Haroldo Malheiros Duclerc. Contratos Mercantis e a Teoria Geral dos Contratos - O Código Civil de 2002 e a Crise do Contrato. São Paulo: Quartier Latin, 2010. Pgs. 42/43.

${ }_{13}$ Artigos 104 e seguintes.

${ }^{14}$ VENOSA, Sílvio de Salvo. Direito Civil - Contratos em Espécie, $7^{\mathrm{a}}$ edição. São Paulo: Editora Atlas, 2007. Pgs. $1 / 4$.

15 JUNQUEIRA, op. cit., 2002. Pg. 21.
} 
Depois da definição conceitual destas duas acepções da forma jurídica, faremos também importante análise neste item, que diz respeito à relação da forma jurídica e a causa do negócio jurídico. Mais especificamente, procuraremos definir o que é a causa do negócio jurídico e qual a sua relação com a forma jurídica, o que nos levará nos capítulos subsequentes a analisar qual a relevância desta inter-relação dos dois institutos para o Direito Tributário.

O Capítulo 6 do nosso estudo será dedicado a analisar os contornos da forma jurídica e a sua relação com a substância do negócio jurídico.

Como mencionado, o conflito entre substância e forma está corriqueiramente inserto nas discussões acerca da definição da tributação aplicável a determinado negócio jurídico. Pretende-se, muitas vezes, que substância do negócio se sobreponha à forma (aqui na acepção forma-estrutura), de maneira a enxergar em tal negócio efeitos econômicos ou não expressamente positivados, fazendo com que a tributação incidente sobre ele observe tais efeitos e não a forma-estrutura inicialmente adotada pelo contribuinte.

É um tema fortemente ligado à elisão tributária, sendo com certeza o foro onde esta discussão ganha maior relevo e amplitude na doutrina, mas não é apenas lá que ele se mostra importante, motivo pelo qual este capítulo também será de utilidade para analisarmos a metodologia de interpretação econômica do fato tributário, a doutrina do propósito negocial, a questão da simulação no Direito Tributário e o abuso de direito.

Nestes campos, a forma jurídica é constantemente colocada em cheque ou simplesmente desconsiderada, motivo pelo qual traremos aqui considerações que entendemos fundamentais para explicitar cada um destes temas, e a partir delas verificarmos a relevância da forma jurídica em contraposição ao que defendem cada uma destas doutrinas.

Ressaltamos que nossas considerações sobre o tema da interpretação econômica, do propósito negocial, da simulação e do abuso de direito não pretendem ser exaustivas, visto que não eles não são o objeto principal do presente trabalho. As considerações sobre estes temas visam ilustrar situações em que a forma jurídica é colocada em xeque, de maneira a se buscar qual o seu real papel e relevância na incidência da norma jurídica tributária.

O Capítulo 7 do trabalho trará a conjugação das lições anteriores, no qual pretenderemos definir o papel da forma jurídica para o Direito Tributário. 
Com efeito, o que buscaremos estudar não é meramente a possibilidade ou não de a substância prevalecer sobre uma determinada forma, mas, além disso, a importância da própria forma em nosso ordenamento, enquanto elemento identificador do negócio jurídico e vinculativo - ou não - de determinados efeitos jurídicos.

Apesar de a discussão entre forma e substância ganha destaque na temática da elisão tributária, ela pode ser verificada nos próprios fundamentos do Direito Tributário, no conflito entre o chamado realismo fiscal e o formalismo fiscal.

Marco Aurélio Greco ${ }^{16}$ já narrou tal contraposição:

O formalismo fiscal, em última análise, sustenta que só pode ser tributada a realidade jurídica que resulta da figura jurídica adotada, tal como se apresenta e com a feição que tem na formulação que assume. Ela vale pelo que formalmente é. (...)

O realismo fiscal postula exatamente o oposto: afirma que o predominante não é a forma adotada; as figuras não valem pela forma de que se revestem; valem pelo que são e não pelo que apresentam ser, nem pelo que resulta da sua apresentação.

Nota-se, claramente, ao longo do desenvolvimento da doutrina tributária, uma polarização entre estes dois extremos. Partimos do formalismo extremo, ao realismo extremo, ou de uma exaltação da forma, para o seu total desprezo ${ }^{17}$.

Em grande parte, esta polarização se deve à chamada interpretação econômica, originada na Alemanha, e cujas origens foram calcadas em um cenário de busca de desenvolvimento econômico e transformação social abrupta em razão de duas grandes guerras $^{18}$. Esta doutrina hoje muitas vezes é invocada como fundamento para propostas de interpretação que deem relevo à substância do negócio jurídico, em detrimento da forma jurídica adotada pelo contribuinte ${ }^{19}$.

${ }^{16}$ GRECO, Marco Aurélio. Planejamento Tributário, $3^{a}$ edição. São Paulo: Editora Dialética, 2011. Pgs. $312 / 313$.

${ }^{17}$ HOFFMANN, Susy Gomes. Breves Considerações sobre os Aspectos Gerais dos Julgamentos, no CARF, de Lançamentos Tributários Envolvendo Planejamento Tributário in Planejamento Fiscal, ANAN JÚNIOR, Pedro (Coord.), Volume III. São Paulo: Quartier Latin, 2013. Pgs.1083/1085.

${ }^{18}$ NOGUEIRA, Johnson Barbosa. A Interpretação Econômica no Direito Tributário. São Paulo: Resenha Tributária, 1982. Pgs. 4/5.

${ }^{19}$ ANDRADE FILHO, Edmar Oliveira. Planejamento Tributário, $2^{a}$ edição, revista, ampliada e atualizada. São Paulo: Saraiva, 2016. Pgs. 255/272. 
Mas como já ressaltado por Marco Aurélio $\mathrm{Greco}^{20}$, “a vida é muito mais complexa do que um ou dois conceitos possam explicar", entendendo que não se pode adotar exclusivamente uma ou outra posição.

Pretendemos localizar o ponto de equilíbrio na leitura destas duas posições extremas.

Será este ponto de equilíbrio que guiará, então, o estudo que propomos, para saber os limites da tributação, em relação aos atos dos contribuintes.

De fato, o particular não é obrigado a praticar determinado ato que configure fato gerador de um tributo.

José Juan Ferreiro Lapatza ${ }^{21}$, aliás, é categórico neste sentido: “está claro, sem que sobre isto se possa admitir a menor dúvida, que a opção entre realizar ou não o pressuposto de fato de um tributo, ou de realizar um ou outro dos fatos imponíveis tipificados nas distintas leis tributárias, está aberta a todos os cidadãos”.

Com efeito, ninguém é obrigado a fazer ou deixar de fazer algo, se não em razão de lei que assim estabeleça ${ }^{22}$.

Mas a discussão maior está na possibilidade de o contribuinte escolher entre duas formas que alcançam um resultado economicamente equivalente, no que Lapatza trata como "economia de opção",23. Embora para este autor não existam dúvidas da possibilidade de tal opção ${ }^{24}$, fato é que o tema ainda é alvo de intenso debate jurisprudencial e doutrinário, a evidenciar a sua importância.

Buscaremos, portanto, analisar a importância da forma no negócio jurídico e o seu reflexo na tributação respectiva, o que, ao fim, nos levará à análise acerca da possibilidade de o contribuinte optar por formas diversas para se alcançar um mesmo resultado, sujeitando-se a diferentes cargas tributárias. Não pretendemos necessariamente concretizar uma doutrina da prevalência da forma sobre a substância, nem pretendemos reviver uma teoria normativista, mas sim entender a dinâmica da forma com a tributação, assim como os seus limites e efeitos no Direito Tributário. Enfim, buscar o ponto de

\footnotetext{
${ }^{20}$ GRECO, op. cit., 2011. Pg. 313.

${ }^{21}$ LAPATZA, José Juan Ferreiro. Direito Tributário, Teoria Geral do Tributo. Barueri: Marcial Pons, 2007a. Pg. 93.

22 BRASIL. Constituição (1988). Constituição da República Federativa do Brasil. Brasília, DF: Senado, 1988. Artigo $5^{\circ}$, inciso II.

${ }^{23}$ Adotando expressão de José Larraz, que, segundo explica Lapatza (Economía de opción, fraude de ley, sanciones y delito fiscal in Quincena Fiscal, Revista de Actualidad Fiscal, Número 8. Madrid: Arazandi, 2001) é a opção de todos os cidadãos entre realizar ou não um fato pressuposto para a incidência do tributo, ou de realizar ou não um fato tipificado nas leis tributárias.

${ }^{24}$ Ibidem. Pgs. 93/96.
} 
equilíbrio entre duas posições extremas (formalismo x realismo) e hoje em constante conflito.

O presente trabalho terá relevante contribuição da doutrina espanhola sobre o Direito Tributário, país no qual tivemos a oportunidade de buscar ensinamentos para complementação deste trabalho, e que, com as devidas ressalvas, servirão de farol para as análises aqui feitas. 


\section{8. - CONCLUSÃO}

\section{1 - Premissas para as conclusões}

O objetivo do presente trabalho foi o de identificar a importância da forma dos negócios jurídicos no Direito Tributário, tarefa esta que não poderia ter sido realizada sem a verificação da própria função da forma jurídica e a sua relevância no Direito como um todo.

A inter-relação do Direito Tributário com outros ramos do Direito também se mostrou um item relevante a ser estudado, visto que somente a partir de tal análise é possível identificar qual o papel da forma jurídica na interpretação e verificação do próprio negócio jurídico.

A partir destas análises, passamos a expor nossas conclusões, de forma sistemática, de maneira a demonstrar a linha de raciocínio aqui construída:

I. O Direito Tributário, assim como outros ramos do Direito, é embasado em princípios que orientam o intérprete e o aplicador do Direito, e que agem como verdadeiras normas.

II. A peculiaridade do Direito Tributário está no fato de que a Constituição Federal de 1988 ter trazido em seu texto importantes normas que delineiam todo o Sistema Nacional Tributário, elevando ao patamar constitucional a grande maioria dos princípios aplicáveis a este ramo do Direito, bem como os limites objetivos que atuam como regra e delimitam a atividade tributante do Estado e orientam o intérprete do Direito Tributário.

III. Há, portanto, coexistência de princípios e regras, com forças normativas distintas em nosso ordenamento, sendo que o conflito de princípios e regras de mesma hierarquia resulta na prevalência da regra, diante do intuito do próprio legislador em positivar com maior força e determinação um certo comando normativo. 
IV. Estas regras, porém, podem de todo modo objetivar o atingimento do estado ideal de coisas perquirido pelo próprio princípio, motivo pelo qual não se pode falar em uma antinomia constante ou permanente entre estes dois tipos de normas. Pelo contrário, a interpretação sistemática da Constituição e de todo o ordenamento deve sempre ser privilegiada pelo intérprete, de maneira a sempre buscar a harmonia normativa.

V. Muitos dos chamados princípios constitucionais que orientam o Direito Tributário podem ser identificados também como regras positivadas pela própria Constituição.

VI. Isto ocorre com a segurança jurídica, com a legalidade e com a capacidade contributiva, que oram atuam como princípios, ora atuam como regras, mas com diferentes destinatários e conteúdo.

VII. É também no contexto constitucional que identificamos os limites e contornos da competência tributária do Entes Federados.

VIII. Da análise sistemática da Constituição, entendemos que o legislador originário fez uso de conceitos de Direito Privado ou de uso corrente pela doutrina, na época de sua promulgação, para fazer a distribuição de competências tributárias.

IX. Tais conceitos não podem ser alterados pelo legislador infraconstitucional, (i) sob pena de trazer insegurança jurídica ao sistema; (ii) por causar injustiças e preterições de grupos sociais ou posições políticas; (iii) e ser de difícil implementação do ponto de vista técnico, tendo em vista a impossibilidade de se identificar a política e o intuito por trás da própria norma constitucional positivada.

X. Permitir que o legislador infraconstitucional defina ou conceitue os signos tributáveis seria permitir que o legislador pudesse alterar a própria Constituição Federal, sendo um contrassenso quando verificada 
a extensa disciplina realizado pelo legislador constituinte e a sua preocupação com a rígida repartição da competência tributária.

XI. Nesse sentido, é preciso buscar no Direito Privado o significado dos conceitos e institutos utilizados pela Constituição. Tais significações também podem ser encontradas no Direito Tributário contemporâneo à Constituição de 1988. Também a própria Constituição pode atribuir determinada significação ou conceituação a um instituto.

XII. As alterações posteriores das definições dos conceitos utilizados pela Constituição para repartição de competência tributária dos Entes Federados não produzem efeitos tributários.

XIII. O legislador tributário, porém, pode atribuir efeitos próprios aos institutos de Direito Privado (que não digam respeito diretamente à repartição de competências constitucionalmente feita), contanto que tais efeitos não sejam incompatíveis com a realidade e observem a repartição de competências tributárias feita pela Constituição, sendo que, os princípios gerais de Direito Privado, embora úteis para auxiliar na definição dos conceitos de Direito Privado, não possuem aplicação na seara tributária.

\section{2 - Conclusões}

As premissas acima são importantes para análise da forma jurídica e a sua relação com a norma tributária. A partir destas premissas, e demais considerações realizadas ao longo deste trabalho, concluímos:

I. Nenhum negócio jurídico existe sem uma forma jurídica, referenciada neste trabalho tanto como sendo critério estrutural do negócio jurídico, necessário para a sua existência e validade (o que chamamos de "forma-formalidade" para fins de referência), como também o conjunto de "formas" necessária para estrutura um negócio jurídico e atender aos requisitos do tipo negocial (que chamamos de "forma-estrutura"). 
II. A forma-formalidade é relevante para (i) dar existência ao negócio jurídico; (ii) nos negócios típicos ou solenes, além de dar existência, dar validade ao negócio; (iii) ainda que de maneira subsidiária ou indireta, definir a natureza de um negócio jurídico típico; ou (iv) definir o regime jurídico de um negócio atípico.

III. Mas apenas a forma-formalidade do negócio não é suficiente para a sua identificação, seja porque a grande maioria dos negócios não possui forma solene, seja porque impera em nosso sistema a liberdade de formas. Não há tipificação e definição de forma exaustiva dos negócios jurídicos, como ocorria, por exemplo, no Direito Romano.

IV. A forma-estrutura seria o próprio negócio jurídico e os elementos necessários para praticá-lo (qualificação de partes, procedimento, substância etc., ao que também se poderia chamar de elementos categoriais de cada tipo de negócio jurídico).

V. A tipificação de um determinado negócio jurídico pode empregar-lhe uma forma-estrutura, ou definir se haverá uma forma-formalidade própria a ser observada, mas mais importante que isso, define e positiva os efeitos jurídicos decorrentes de tal negócio.

VI. Tais efeitos práticos são identificados como a causa do negócio que, embora esteja mais evidenciada no negócio típico, está presente em qualquer negócio jurídico. A causa pode ser abstrata ou concreta.

VII. A causa abstrata é a função socioeconômica do negócio jurídico, que quando juridicizada é tipificada; é a previsão normativa da função do negócio. A causa concreta, por sua vez, é a função prático-individual objetivada.

VIII. O tipo de um negócio jurídico ou contrato, portanto, é a juridicização da causa, isto é, é a atribuição de efeitos jurídicos a uma finalidade econômico-social inerente a determinados atos da vida cotidiana. 
IX. Apenas a causa concreta, porém, não é suficiente para determinar os efeitos jurídicos do negócio, pois se o negócio não atender aos demais elementos do tipo, ou exigidos de maneira geral pela legislação, não será ele válido e eventualmente será nulo. Nesse sentido, a forma atua como critério dos mais relevantes em tal verificação.

X. A conjugação dos dois elementos, forma e causa concreta, assim, determina a natureza jurídica do negócio, ao possibilitar o seu enquadramento no tipo negocial previsto pelo ordenamento e atraindo o regime jurídico aplicável a tal tipo.

XI. Em outras palavras, é a causa concreta que individualiza o negócio e serve para identificá-lo, mas é preciso verificar se a forma também restou atendida, sob pena de nulidade ou invalidade do negócio ou não enquadramento em um determinado tipo jurídico, o que lhe impediria de usufruir os efeitos jurídicos atribuídos pelo ordenamento a tal tipo.

XII. Nesse sentido, verificamos que essa inter-relação entre forma e causa ou substância evidencia serem eles elementos intrínsecos.

XIII. A aparente dicotomia entre forma e substância não se mostra cientificamente correta, pois a forma e a substância de um determinado negócio, na verdade, são complementos de uma mesma realidade. O Direito é forma em sua essência e a exigência de uma forma específica para externar a vontade e formalizar a sua declaração tem como propósito dar a própria existência ao negócio jurídico, do que não pode se dissociar de sua substância.

XIV. A substanciado negócio pode ser associada à causa concreta do negócio jurídico. Os efeitos econômicos buscados pelas partes, depois de juridicizados, ganham efeitos jurídicos e se traduzem na causa. Estes efeitos são a substância do negócio jurídico.

XV. Toda forma possui uma substância que lhe é intrínseca e toda substância está amparada em uma forma. E esta relação íntima entre 
forma e substância é também o que justifica a sua relação com a causa do negócio jurídico.

XVI. A conjugação entre a forma jurídica do negócio e a sua causa é o que dá validade ao negócio e permite a sua própria identificação. Como visto, apenas a análise do objeto do negócio não é suficiente para identificar a sua natureza, embora possa complementar tal verificação.

XVII. Esta conjugação fica ainda mais evidente quando consideramos que a própria legislação tributária por vezes alia uma forma jurídica a uma determinada causa, de maneira a induzir determinado comportamento do contribuinte, reconhecendo que tal conjugação é válida para condicionar um determinado efeito tributário.

XVIII. Assim, verificamos que tentativas de requalificação do negócio jurídico com base em uma interpretação econômica, ou com base em argumentos de verificação de propósito negocial extra-tributários, ou mesmo em razão de abuso de direito ou formas não possuem previsão normativa ou justificativa em nosso ordenamento.

XIX. Também o propósito de economia de tributos não pode servir de pretexto para uma requalificação ou tributação.

XX. É preciso verificar em quais situações a legislação tributária permite a requalificação do negócio jurídico, assim como é preciso verificar em tal legislação a existência de procedimentos para tanto. Inexistindo tais previsões, deve-se recorrer ao Direito Civil, que, como visto acima, guarda os institutos e conceitos dos quais se vale o próprio Direito Tributário.

XXI. Assim, a única requalificação prevista pelo ordenamento é aquela motivada pela simulação, por previsão do CTN, em seus artigos 116 e 149.

XXII. Mas a requalificação não pode ser feita sem critérios. Dada a inexistência de tal disciplina na legislação tributária, deve a 
Administração observar os limites constantes do Direito Privado para tal função.

XXIII. Nesse sentido, é de se verificar que a legislação privada autoriza a desconsideração do negócio jurídico simulado, com a manutenção do negócio dissimulado, contanto que a forma e a substância sejam válidas.

XXIV. Isto é, não se pode desqualificar o negócio jurídico e pretender imputar efeitos quaisquer ao negócio jurídico subsistente, se a ele houver uma forma própria ou substância não atendida pelas partes. Deve-se buscar exatamente qual a causa concreta pretendida pelas partes e que estava encoberta pelo negócio simulado, mas não se pode atribuir mais efeitos do que aqueles que as próprias partes pretendiam.

XXV. Nesta atividade a capacidade contributiva não pode se sobrepor à legalidade para fins de tributação, em razão da força normativa distinta destas duas normas (capacidade contributiva enquanto princípio $\mathrm{x}$ legalidade enquanto regra), de forma que não havendo a previsão de tributação de determinado fato jurídico pela lei, não poderá a capacidade contributiva querer alcançar tal fato, desconsiderando a forma e a causa do negócio jurídico, que, conjugados, emanam determinados efeitos que serão ou não captados pela legislação à luz da Constituição.

XXVI. Um pretenso efeito positivo da capacidade contributiva esbarra na legalidade enquanto regra, bem como não está abarcada pela própria acepção e conceito deste instituto enquanto princípio e enquanto regra.

XXVII. Desta forma, o efeito positivo da capacidade contributiva não teria o condão de tornar tributável um negócio jurídico, tendo em vista que não é o negócio jurídico em si que é alvo da tributação, mas sim os efeitos decorrentes de tais negócios ou objetos neles contidos e tais efeitos eleitos pelo constituinte para se submeter à tributação estão já definidos 
e conceituados juridicamente na própria Constituição ou na legislação a ela contemporânea.

XXVIII. Havendo referência legislativa à tributação de um negócio jurídico, sem especificar qual manifestação de riqueza exatamente é objetivada por tal norma, de rigor se reconhecer a sua inconstitucionalidade por não atendimento da legalidade estrita e da própria capacidade contributiva enquanto regra.

XXIX. Uma forma jurídica que esteja em consonância com a causa concreta eleita pela parte, assim, vincula a Administração, não podendo ser desconsiderada apenas a pretexto de se tributar mais gravosamente a operação.

XXX. Havendo a dissonância da forma e da causa, porém, estará configurada a simulação, que autorizará uma requalificação, ou melhor, a identificação do verdadeiro negócio jurídico praticado, se não houver requisito de forma ou substância para a sua existência, que não tenha sido atendido pelas partes.

XXXI. É preciso notar, porém, que muitas referências feitas pela doutrina e pela jurisprudência nacional à forma e substância não observam o rigor técnico necessário, muitas vezes confundindo a forma jurídica com a mera nomenclatura ou denominação dada pelo contribuinte a um determinado negócio concreto, ou mesmo confundindo a forma jurídica com o instrumento contratual (suporte físico). O que muitas vezes se chama de requalificação, na verdade, é apenas o trabalho de identificação da própria natureza do negócio e verificação de seus efeitos. Nem sempre a denominação equivocada de um negócio ou contrato estará evidenciando uma situação de simulação.

XXXII. A forma jurídica, porém, como visto acima, não está necessariamente vinculada à vontade da parte, mas sim é imposição para a existência ou validade do negócio jurídico e se relacionada com um negócio típico, 
evidenciará os efeitos atribuídos pelo ordenamento a tal negócio, os quais independerão dos motivos subjetivos das partes.

XXXIII. Considerando que a Constituição Federal autoriza a tributação de efeitos de negócios jurídicos ou de objetos de negócios jurídicos, nunca mirando um determinado negócio jurídico em si, a forma jurídica, é de todo relevante para a tributação, visto que, é da conjugação da forma e da causa do negócio que se identifica a sua natureza (e tipo, a depender do caso), do que será possível extrair quais os efeitos jurídicos atribuídos a tal negócio pelo ordenamento e, consequentemente, verificar-se qual a tributação aplicável.

XXXIV. A necessidade da conjugação da forma com a causa concreta do negócio não pode ser negada, sendo possível afirmar que, em havendo consonância entre estes dois institutos, não poderá a Administração pretender desconsiderar ou requalificar tal negócio. 


\section{9. - BIBLIOGRAFIA}

- ALEXY, Robert. Teoria de los Derechos Fundamentales. Madrid: Centro de Estudios Constitucionales, 1997.

- AMARO, Luciano. Direito Tributário Brasileiro, 18ª edição. São Paulo: Saraiva, 2012.

- ANDRADE FILHO, Edmar Oliveira. Planejamento Tributário, $2^{\mathrm{a}}$ edição, revista, ampliada e atualizada. São Paulo: Saraiva, 2016.

- ANDRADE, José Maria Arruda de. Interpretação da Norma Tributária. São Paulo: MP Editora, 2006.

Hermenêutica Jurídica e a Questão da Textura Aberta in Revista da Faculdade de Direito da Universidade de São Paulo, volume 103. São Paulo: USP, 2008.

Interpretação e Aplicação da Lei Tributária: da Consideração

Econômica da Norma Tributária à Análise Econômica do Direito in Interpretação e Aplicação da Lei Tributária, MACHADO, Hugo de Brito (Coord.). São Paulo: Dialética, 2010.

- ANDRADE JÚNIOR, Luiz Carlos de. A Simulação no Direito Civil. São Paulo: Malheiros, 2016.

- AQUINO, Santo Tomás de. O Ente e a essência in Os Pensadores, volume 8. São Paulo: Abril Cultural, 1973

- ASCENSÃO, José de Oliveira. Direito Civil, volume 3, 2a edição. São Paulo: Saraiva, 2010.

- ASSEIS, Pedro Augusto do Amaral Abujamra. A importância do "Propósito Negocial" no Planejamento Tributário: Análise à Luz dos Recentes Julgamentos do Carf sobre a Amortização Fiscal do Ágio in Revista de Direito Tributário Atual, volume 29. São Paulo: Dialética, 2013.

- ATALIBA, Geraldo. Sistema Constitucional Tributário Brasileiro. São Paulo: Revista dos Tribunais, 1968.

Hipótese de Incidência Tributária, $6^{\text {a }}$ edição. São Paulo: Malheiros,

2004.

República e Constituição, $3^{a}$ edição. São Paulo: Malheiros, 2011.

- ATIEnZA, Manuel e MANERO, Juan Ruiz. Ilícitos Atípicos. Sobre o Abuso de

Direito, Fraude à Lei e Desvio de Poder, tradução Janaina Roland Matida. São Paulo: Marcial Pons, 2014. 
- ÁVILA, Humberto. Eficácia do Novo Código Civil na Legislação Tributária in Direito Tributário e o Novo Código Civil, GRUPENMACHER, Betina Treiger (Coord.). São Paulo: Quartier Latin, 2004.

Limites à Tributação com Base na Solidariedade Social in

Solidariedade Social e Tributação, GRECO, Marco Aurélio (Coord.). São Paulo: Dialética, 2005.

A teoria dos princípios e o Direito Tributário in Revista Dialética de Direito Tributário, volume 125. São Paulo: Editora Oliveira Rocha, 2006a.

Imposto sobre a Prestação de Serviços de Qualquer Natureza.

Exportação de Serviços. Lei Complementar $n^{0}$ 116/2003. Isenção: Requisitos e Alcances. Conceitos de "Desenvolvimento" de Serviço e "Verificação" de seu Resultado in Revista Dialética de Direito Tributário, volume 134. São Paulo: Dialética, 2006b.

Planejamento Tributário in XX Congresso Brasileiro de Direito Tributário. São Paulo: Malheiros, 2006c.

O “Postulado do Legislador Coerente" e a Não-cumulatividade das Contribuições in Grandes Questões Atuais do Direito Tributário, volume 11. São Paulo: Dialética, 2007.

$-$

. Regra-Matriz versus Princípios in Direito Tributário - Homenagem a Paulo de Barros Carvalho. São Paulo: Quartier Latin, 2008.

. Sistema Constitucional Tributário, $4^{\mathrm{a}}$ edição. São Paulo: Editora

Saraiva, 2010.

. Segurança Jurídica, entre permanência, mudança e realização no

Direito Tributário, 2a edição. São Paulo: Malheiros, 2012.

Teoria dos Princípios, da definição à aplicação dos princípios

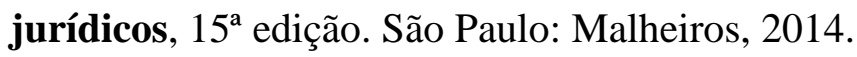

- AZEVEDO, Álvaro Villaça. Direito Privado: Casos e Pareceres. São Paulo: IASP, 1986.

- AZEVEDO, Antônio Junqueira de. Negócio Jurídico e Declaração negocial (Noções Gerais e Formação da Declaração Negocial), Tese para Concurso de Professor Titular da Faculdade de Direito da Universidade de São Paulo, 1986.

Negócio Jurídico, Existência, Validade e Eficácia. São Paulo:

Saraiva, 2002. 
- BALEEIRO, Aliomar. Limitações Constitucionais ao Poder de Tributar, $8^{a}$ edição. Rio de Janeiro: Forense, 2010.

- BARRETO, Aires Fernandino. Base de cálculo, alíquota e princípios constitucionais. São Paulo: Max Limonad, 1998.
-__ Curso de Direito Tributário Municipal. São Paulo: Saraiva, 2009a.
- __ _ ISS na Constituição e na Lei. São Paulo: Dialética, 2009b.
- _ _ ISS, IOF e Instituições Financeiras. São Paulo: Noeses, 2016.
- BARRETO, Paulo Ayres. Imposto sobre a Renda e Preços de Transferência. Dialética: São Paulo, 2001.

. Planejamento Tributário: Perspectivas Teóricas e Práticas in Revista de Direito Tributário, volume 105. São Paulo: Malheiros, 2004.

_. Contribuições: regime jurídico, destinação e controle. São Paulo:

Editora Noeses, 2006.

- _ Elisão Tributária: Limites Normativos. São Paulo: USP, 2008.
- $\ldots$ Conceitos Constitucionais e Competência Tributária in Temas de direito Tributário, estudos em homenagem a Eduardo Bottallo, SANTOS, Nélida Cristina dos; LIMA, José Antonio Balieiro; FRIGO JUNIOR, Gilberto (Coords.). São Paulo: Saraiva, 2013.

- Ordenamento e sistema jurídicos in Constructivismo lógicosemântico, CARVALHO, Paulo de Barros (Coord.) e CARVALHO, Aurora Tomazini de (Org.), volume 1. São Paulo: Noeses, 2014.

- _. Planejamento Tributário: Limites Normativos. São Paulo: Noeses, 2016.

- BARRETO, Aires Fernandino e BARRETO, Paulo Ayres. Imunidades Constitucionais: Limitações Constitucionais ao Poder de Tributar. São Paulo: Dialética, 2001.

- BARROS, José Eduardo Monteiro de. Interpretação Econômica em Direito Tributário in Interpretação no Direito Tributário, ATALIBA, Geraldo (Coord.). São Paulo: Saraiva e EDUC, 1975.

- BECKER, Alfredo Augusto. Teoria Geral do Direito Tributário, $3^{\text {a }}$ edição: São Paulo: Editora Lejus, 2002.

- BEISSE, Heinrich. O critério econômico na interpretação das leis tributárias segundo a mais recente jurisprudência alemã in Direito Tributário - Estudos em Homenagem ao Prof. Ruy Barbosa Nogueira. São Paulo: Saraiva, 1984. 
- BETTI, Emilio. Teoria Generale del Negozio Giuridico. Napoli: Edizioni Scientifiche Italiane, 2002.

Teoria Geral do Negócio Jurídico, tradução: Servanda Editora.

Campinas: Servanda Editora, 2008.

- BOBBIO, Norberto. Teoria do Ordenamento Jurídico, 10ª edição. Brasília: Editora Universidade de Brasília, 2006.

- BORGES, José Souto Maior. Obrigação Tributária (Uma Introdução Metodológica), $3^{a}$ edição, revista e ampliada. São Paulo: Malheiros, 2015.

- BOZZA, Fábio Piovesan. Planejamento Tributário e Autonomia Privada. São Paulo: Quartier Latin, 2015.

- BOZZA, Fábio Piovesan; MATOS, Gustavo Martini e OLIVERIA, Ricardo Mariz de. Interpretação e Interação da Lei Tributária in Interpretação e Aplicação da Lei Tributária, MACHADO, Hugo de Brito (Coord.). São Paulo: Dialética, 2010.

- BRAZUNA, José Luiz Ribeiro. A Consideração Econômica e o Abuso de Formas no Direito Tributário Brasileiro in Revista Fórum de Direito Tributário, volume 20. Belo Horizonte: Fórum, 2006.

- BRITO, Edvaldo. Interpretação Econômica da Norma Tributária e o Planejamento Tributário in O Planejamento Tributário e a Lei Complementar 104, ROCHA, Valdir de Oliveira (Coord.). São Paulo: Dialética, 2002.

- BUERES, Alberto J. Objeto del Negocio Jurídico, 2a edição. Buenos Aires: Editorial Hammurabi, 1998.

- BUJANDA, Fernando Sainz. Poder Financeiro in Notas de Derecho Financeiro, redactadas em el seminário de Derecho Financeiro, tomo I, volume 2. Madrid: Universidade de Madrid, 1967.

- BULGARELLI, Waldirio. Contratos Mercantis, 9a edição. São Paulo: Atlas, 1997.

- BUXADÉ, Antonio Durán-Sindreu. Los Motivos Económicos Válidos como Técnica Contra la Elusión Fiscal: Economía de Opción, Autonomía de Voluntad y Causa en los Negocios. Navarra: Editora Aranzadi, 2007.

- CALAMANDREI, Piero. La Casación Civil, Tomo II, tradução de Santiago Sentis Melendo. Buenos Aires: Editorial Bibliográfica Argentina, 1945.

- CANTO, Gilberto de Ulhôa. Temas de Direito Tributário, volume primeiro. Rio de Janeiro: Editora Alba Limitada, 1963. 
Elisão e Evasão Fiscal in Caderno de Pesquisas Tributárias, volume 13 - Elisão e Evasão Fiscal, MARTINS, Ives Gandra da Silva (Coord.). São Paulo: Resenha Tributária e Centro de Estudos de Extensão Universitária, 1988.

- CARRAZZA, Roque Antonio. Curso de Direito Constitucional Tributário, $26^{a}$ edição. São Paulo: Malheiros, 2010a.

Reflexões sobre a Obrigação Tributária. São Paulo: Noeses, 2010b. Curso de Direito Constitucional Tributário, $27^{a}$ edição. São Paulo:

Malheiros, 2011.

ICMS. São Paulo: Malheiros, 2015.

- CARUSI, Franco. La Causa dei Negozi Giuridici e L'auntonomia dela Volontà nel Direitto Privato Italiano. Napoli: Conte, 1947.

- CARVAlho, Cristiano e TRINDADE, Manoel Gustavo Neubarth. A Superação de Regras por Princípios Jurídicos na Atividade Jurisdicional: um Enfoque pela Análise Econômica do Direito in Revista de Direito Tributário, volume 109/110. São Paulo: Malheiros, 2005.

- CARVAlhO, Paulo de Barros. Curso de Direito Tributário, $21^{a}$ edição. São Paulo: Saraiva, 2009a. Direito Tributário, Linguagem e Método. São Paulo: Noeses, 2008 e $2009 b$. . Princípios e Sobreprincípios na Interpretação do Direito in Direito Tributário em Questão, volume 7. Porto Alegre: Revista da FESDT, 2011.

Direito Tributário: Fundamentos Jurídicos da Incidência, 10 edição, revista e atualizada. São Paulo: Saraiva, 2015.

Planejamento Tributário e a Doutrina da Prevalência da

Substância sobre a Forma na Definição dos Efeitos Tributários de um Negócio Jurídico in Planejamento Tributário, MACHADO, Hugo de Brito (Coord.). São Paulo: Malheiros: ICET, 2016.

O Absurdo da Interpretação Econômica do Fato Gerador: Direito e sua Autonomia - O Paradoxo da Interdisciplinaridade in CTN 50 Anos com Eficácia de Lei Complementar (1967-2017), MARTINS, Ives Gandra da Silva et.al. (Coord.). São Paulo: Conselho Superior de Direito da FECOMERCIO-SP.

- CASSONE, Vittorio. Interpretação no Direito Tributário, Teoria e Prática. São Paulo: Editora Atlas, 2004. 
- CASTRO, Torquato. Da Causa no Contrato. Recife: Imprensa Universitária, 1968.

- CIAN, Giorgio. Forma Solenne e Interpretazione del Negozio. Padova: CEDAM, 1969.

- COELHO, Luiz Fernando. Lógica Jurídica e Interpretação das Leis, $2^{a}$ edição, revista. Rio de Janeiro: Forense, 1981.

- COÊLHO, Sacha Calmon Navarro. Curso de Direito Tributário Brasileiro. Rio de Janeiro: Forense, 1999.

- Os Limites Atuais do Planejamento Tributário (Apreciação Crítica da Lei Complementar $n^{0}$ 104, de 10 de janeiro de 2001, que procura introduzir no Brasil a "Interpretação Econômica do Direito Tributário" ou a Chamada "Norma Geral Antuelisiva) in O Planejamento Tributário e a Lei Complementar 104, ROCHA, Valdir de Oliveira (Coord.). São Paulo: Dialética, 2002. Evasão e Elisão Fiscal. O Parágrafo Único do Art. 116, CTN, e o

Direito Comparado. Rio de Janeiro: Forense, 2006.

Legislação Tributária in Interpretação e Aplicação da Lei Tributária, MACHADO, Hugo de Brito (Coord.). São Paulo: Dialética, 2010.

Considerações Acerca do Planejamento Tributário no Brasil in

Planejamento Tributário, MACHADO, Hugo de Brito (Coord.). São Paulo: Malheiros: ICET, 2016.

- COSTA, Alcides Jorge. Direito Tributário e Direito Privado in Direito Tributário Estudos em Homenagem ao Prof. Ruy Barbosa Nogueira. São Paulo: Saraiva, 1984.

- COSTA, Regina Helena. Princípio da Capacidade Contributiva, $4^{\text {a }}$ edição, atualizada, revista e ampliada. São Paulo: Malheiros, 2012.

Curso de Direito Tributário, Constituição e Código Tributário

Nacional, $3^{\text {a }}$ edição, revista, atualizada e ampliada. São Paulo: Saraiva, 2013.

- D'AMATO, Anthony. The Injustice of Dynamic Statutory Interpretation, Faculty Working paper 87. Northwestern University School of Law, 2010.

- DENARI, Zelmo. A Interpretação Econômica do Nosso Sistema Tributário in Revista de Direito Tributário, volume 55. São Paulo: Revista dos Tribunais, 1991.

- DERZI, Misabel de Abreu Machado. Direito Tributário, Direito Penal e Tipo. São Paulo: Revista dos Tribunais, 1988. 
. O Princípio da Preservação das Empresas e o Direito à Economia

de Impostos in Grandes Questões Atuais do Direito Tributário, volume 10. São Paulo: Dialética, 2006.

- DIAS, Karem Jureidini. Fato Tributário, Revisão e Efeitos Jurídicos. São Paulo: Noeses, 2013.

- DINAMARCO, Cândido Rangel. Fundamentos do Processo Civil Moderno, Tomo I, $6^{\text {a }}$ edição. São Paulo: Malheiros, 2010.

- DÓRIA, Antônio Roberto Sampaio. DÓRIA, Antônio Roberto Sampaio. Da Lei Tributária no Tempo. São Paulo: Obelisco, 1968.

Elisão e Evasão Fiscal. São Paulo: Lael, 1971.

- DWORKIN, Ronald. Levando os direitos a sério (Taking Rights Seriously), tradução e notas de Nelson Boeira, $1^{\text {a }}$ edição. São Paulo: Martins Fontes, 2002.

- ESKRIDGE, William N. Jr.. Dynamic Statutory Interpretation, Faculty Scholarship Series, paper 1505. Yale Law School, 1987.

- FALCÃO, Amílcar Araújo. Introdução ao Direito Tributário, NOVELLI, Flávio Bauer (atualizador), $5^{\text {a }}$ edição. Rio de Janeiro: Forense, 1994.

Forense, 1997.

- FERRARA, Francisco. A Simulação dos Negócios Jurídicos. São Paulo: Red Livros, 1999.

- FERRAZ JÚNIOR, Tércio Sampaio. Direito Constitucional, Liberdade de Fumar, Privacidade, Estado, Direitos Humanos e Outros Temas. São Paulo: Manole, 2007.

- FERREIRA, Vasco Taborda. Do Conceito de Causa dos Actos Jurídicos. Lisboa: Silvas, 1946.

- FLUSSER, Vilém. Língua e realidade. São Paulo: Annablume, 2004.

- FONROUGE, Giuliani. Conceitos de Direito Tributário, tradução de Geraldo Ataliba e Marco Aurélio Greco. São Paulo: Edições Lael, 1973.

- FORGIONI, Paula Andrea. Contratos Empresariais, Teoria Geral e Aplicação. São Paulo: Editora Revista dos Tribunais, 2015.

- FRANCO SOBRINHO, Manoel de Oliveira. A prova Administrativa. São Paulo: Saraiva, 1973.

- FREITAS, Rodrigo de. É Legítimo Economizar Tributos? Propósito Negocial, Causa do Negócio Jurídico e Análise das Decisões do Antigo Conselho de Contribuintes in 
Planejamento Tributário e o "Propósito Negocial”, SCHOUERI, Luís Eduardo (coord.). São Paulo: Quartier Latin, 2010.

- GAMA, Tácio Lacerda. Competência Tributária e a sua Estrutura Normativa in Revista de Direito Tributário, volume 102. São Paulo: Malheiros, 2008.

Competência Tributária, Fundamentos para uma Teoria da

Nulidade. São Paulo: Noeses, 2009.

Critérios de Admissibilidade Versus Critérios para

Desconsideração de Planejamento Tributário in Revista de Direito Tributário, volume 125. São Paulo: Malheiros, 2016.

- GODOI, Marciano Seabra de; e SALIBA, Luciana Goulart Ferreira. Interpretação e Aplicação da Lei Tributária in Interpretação e Aplicação da Lei Tributária, MACHADO, Hugo de Brito (Coord.). São Paulo: Dialética, 2010.

- Gogliano, Daisy. A Função Social do Contrato (Causa e Motivo) in Revista da Faculdade de Direito da Universidade de São Paulo, volume 99. São Paulo: USP, 2004.

- GRAU, Eros. O Direito Posto e o Direito Pressuposto. São Paulo: Malheiros, 1996.

- GRECO, Marco Aurélio. Solidariedade Social e Tributação in Solidariedade Social e Tributação, GRECO, Marco Aurélio (Coord.). São Paulo: Dialética, 2005. Planejamento Tributário, $3^{\mathrm{a}}$ edição. São Paulo: Editora Dialética, 2011.

- GUASTINI, Ricardo. Distinguiendo: Estúdios de Teoria y Metateoria del Derecho, tradução de Jordi Ferrer i Beltran. Barcelona: Gedisa, 1999.

- HARET, Florence. Teoria e Prática das Presunções no Direito Tributário. São Paulo: Noeses, 2010.

- HOFFMANN, Susy Gomes. Considerações sobre a Presunção de Legitimidade do Lançamento Tributário e sua Relação com as Provas in Revista de Direito Tributário, volume 72. São Paulo: Malheiros, 1999.

. Breves Considerações sobre os Aspectos Gerais dos Julgamentos, no CARF, de Lançamentos Tributários Envolvendo Planejamento Tributário in Planejamento Fiscal, ANAN JÚNIOR, Pedro (Coord.), Volume III. São Paulo: Quartier Latin, 2013.

- HUCK, Hermes Marcelo. Evasão e Elisão, Rotas Nacionais e Internacionais do Planejamento Tributário. Tese apresentada ao concurso de professor titular da Faculdade de Direito da Universidade de São Paulo, 1996. 
- JARACH, Dino. El Hecho Imponible. Teoría General del Derecho Tributário Substantivo. Buenos Aires: Abeledo Perrot, 1971

Hermenêutica do Direito Tributário in Interpretação no Direito

Tributário, ATALIBA, Geraldo (Coord.). São Paulo: Saraiva e EDUC, 1975.

- KATAOKA, Eduardo Takemi. A Coligação Contratual. Rio de Janeiro: Editora Lumen Juris, 2008.

- KELSEN, Hans. Teoria Pura do Direito, tradução de João Bapstista Machado. São Paulo: Martins Fontes, 2006.

- LAPATZA, José Juan Ferreiro. Economía de opción, fraude de ley, sanciones y delito fiscal in Quincena Fiscal, Revista de Actualidad Fiscal, Número 8. Madrid: Arazandi, 2001.

La Nueva Ley General Tributaria (Ley 58/2003, de 17 de diciembre). Madrid: Marcial Pons, 2004.

Curso de Derecho Financeiro Español - Instituciones, 25 a edição.

Madrid: Marcial Pons, 2006.

$2007 \mathrm{a}$.

. Direito Tributário, Teoria Geral do Tributo. Barueri: Marcial Pons,

\section{7 .}

. Legalidad, Antielusión y Pacto em El Ordenamiento Tributario in

Estudios in homenaje al professor Péres de Ayala, GARCÍA-QUINTANA, Cesar Albiñana; GARCÍA, Eusebio González; MASSANET, Juan Ramallo; VALCÁRCEL, Ernesto Lejeune; e STERLING, Ana Yábar (Coords.). Madrid: Dykinson, 2007b.

- LARENZ, Karl. Metodologia da Ciência do Direito. Lisboa; Fundação Calouste Gulbernkian, 2009.

- LARRAZ, Jose. Metodologia Aplicativa del Derecho Tributario. Madrid: Revista de Derecho Privado, 1952.

- LINS, Robson Maia. Controle de Constitucionalidade da Norma Tributária Decadência e Prescrição. São Paulo: Quartier Latin, 2005.

Sanção e Confisco - Limites Normativos e a Jurisprudência in

Revista de Direito Tributário, no 121. São Paulo: Malheiros, 2014.

- LOPES, Alexsandro Broedel e MOSQUERA, Roberto Quiroga. O Direito Contábil Fundamentos Conceituais, Aspectos da Experiência Brasileira e Implicações in Controvérsias Jurídico-Contábeis (aproximações e distanciamentos). São Paulo: Dialética, 2010. 
- LOPES, Miguel Maria de Serpa. Curso de Direito Civil, volume I, $3^{\text {a }}$ edição. Rio de Janeiro: Freitas Bastos, 1960.

- MACHADO SEGUNDO, Hugo de Brito. Processo Tributário. São Paulo: Atlas, 2004.

- MACHADO, Hugo de Brito. Evasão Tributária in Caderno de Pesquisas Tributárias, volume 13 - Elisão e Evasão Fiscal, MARTINS, Ives Gandra da Silva (Coord.). São Paulo: Resenha Tributária e Centro de Estudos de Extensão Universitária, 1988.

Interpretação e Aplicação das Leis Tributárias in Interpretação e Aplicação da Lei Tributária, MACHADO, Hugo de Brito (Coord.). São Paulo: Dialética, 2010.

Introdução ao Planejamento Tributário. São Paulo: Malheiros, 2014.

Planejamento Tributário in Planejamento Tributário, MACHADO, Hugo de Brito (Coord.). São Paulo: Malheiros: ICET, 2016.

- MARINO, Francisco Paulo De Crescenzo. Contratos Coligados no Direito Brasileiro, $1^{a}$ Edição, $2^{a}$ Tiragem. São Paulo: Saraiva, 2009.

- MARINS, James. Elisão Tributária e sua Regulação. São Paulo: Dialética, 2002.

- MCNAUGHTON, Charles William. Hierarquia e Sistema Tributário. São Paulo: Quartier Latin, 2011.

- MELlo, Marcos Bernardes de. Teoria do Fato Jurídico, Plano da Existência, 14 edição. São Paulo: Saraiva, 2007.

- MELO, José Eduardo Soares. ICMS - Teoria e Prática. São Paulo: Dialética, 2005.

- MIRANDA, Pontes de. Tratado de Direito Privado, Parte Geral, Negócios Jurídicos,

Tomo III, MELLO, Marcos Bernardes de e EHRHARDT Jr., Marcos (atualizadores). São Paulo: Revista dos Tribunais, 2012.

. Tratado de Direito Privado, Parte Geral, Validade, Nulidade,

Anulabilidade, Tomo IV, MELLO, Marcos Bernardes de e EHRHARDT Jr., Marcos (atualizadores). São Paulo: Revista dos Tribunais, 2012.

Tratado de Direito Privado, Parte Especial, Direito das

Obrigações, Negócios Jurídicos Bilaterais, Tomo XXXVIII, MELLO, Marcos Bernardes de e EHRHARDT Jr., Marcos (atualizadores). São Paulo: Revista dos Tribunais, 2012.

- MIRANDA, Custódio da Piedade Ubaldino. Teoria Geral do Negócio Jurídico. São Paulo: Atlas, 1991. 
- MORAES, Maria Cecília Bodin de. A Causa dos Contratos in Revista Trimestral de Direito Civil, Volume 21. Rio de Janeiro: Padma, 2005.

- MOSQUERA, Roberto Quiroga. Planejamento Fiscal, Evasão e Propósito Negocial in Revista de Direito Tributário, volume 107/108. São Paulo: Malheiros, 2008.

- MOTTA, Antonio. La Causa del Obbligazioni nel Direitto Civile Italiano. Torino: Fratelli Bocca, 1929.

- MOUSSALlEM, Tárek Moysés. Classificação dos Tributos - Uma visão analítica in IV Congresso Nacional de Estudos Tributários - Tributação e Processo. São Paulo: Noeses, 2007.

. Revogação em Matéria Tributária, $2^{a}$ edição. São Paulo: Noeses, 2011.

- NABAIS, José Casalta. Direito Fiscal. Coimbra: Almedina, 2002.

- NERY JÚNIOR, Nelson. Vícios do Ato Jurídico e Reserva Mental. São Paulo: Revista dos Tribunais, 1983.

- NOGUEIRA, Johnson Barbosa. A Interpretação Econômica no Direito Tributário. São Paulo: Resenha Tributária, 1982.

- NOGUEIRA, Ruy Barbosa. Direito Financeiro - Curso de Direito Tributário, $3^{\text {a }}$ Edição. São Paulo: José Bushatsky Editor, 1971.

$-$

. Da interpretação e da aplicação das leis tributárias, $2^{a}$ edição. São

Paulo: José Bushatsky Editor, 1974.

. Curso de Direito Tributário, 15ª Edição. São Paulo: Saraiva, 1999.

- NOVOA, César García. La Cláusula Antielusiva em La Nueva Lei General Tributaria. Madrid: Marcial Pons, 2004.

- OLIVEIRA, Ricardo Mariz. Elisão e Evasão Fiscal in Caderno de Pesquisas Tributárias, volume 13 - Elisão e Evasão Fiscal, MARTINS, Ives Gandra da Silva (Coord.). São Paulo: Resenha Tributária e Centro de Estudos de Extensão Universitária, 1988.

. A Elisão Fiscal ante a Lei Complementar n' 104 in O Planejamento Tributário e a Lei Complementar 104, ROCHA, Valdir de Oliveira (Coord.). São Paulo: Dialética, 2002.

. Reflexos do Novo Código Civil no Direito Brasileiro in Revista de

Estudos Tributários, volume 5. Porto Alegre: Síntese, 2003. Disponível também em < http://www.marizsiqueira.com.br/Artigos.html>. Acesso em 27 de março de 2017. 
"Pro Memoria" de Palestra sobre "Planejamento Tributário: Limites Objetivos e Oponibilidade ao Fisco", no I Congresso IBDT/AJUFE de Direito Tributário Brasileiro.

Disponível

em

<http://www.ibdt.com.br/Congresso2008_PainelI_RicardoMarizdeOliveira.pdf〉. Acesso em 27 de março de 2017.

. Os Motivos e os Fundamentos Econômicos dos Ágios e Deságios na

Aquisição de Investimentos, na Perspectiva da Legislação Tributária in Revista Direito Tributário Atual, volume 23. São Paulo: Dialética, 2009. Disponível também em < http://www.marizsiqueira.com.br/Artigos.html>. Acesso em 27 de março de 2017.

- PACIELLO, Gaetano e ROTHMANN, Gerd Willi. Elisão e Evasão Fiscal in Caderno de Pesquisas Tributárias, volume 13 - Elisão e Evasão Fiscal, MARTINS, Ives Gandra da Silva (Coord.). São Paulo: Resenha Tributária e Centro de Estudos de Extensão Universitária, 1988.

- PALMA, Clotilde Celorico. La Evolución Conceptual del Principio de Capacidad Contributiva in La Capacidade Contributiva, Presupuesto Jurídico y Fundamento de La Tributación. Conferencia Técnica do Centro Interamericano de Administraciones Tributarias (CIAT) de 2000. Madrid: Instituto de Estudios Fiscales, 2002.

- PEDROCHE, J. Andrés Sánchez. Forma y Materia em Derecho Financeiro y Tributario. Incumplimiento de obligaciones formales $y$ perdida de derechos sustanciales. Madrid: Centro de Estudios Financeiros, 2004.

- POLIZELLI, Victor Borges. O Princípio da Realização da Renda - Reconhecimento de Receitas e Despesas para Fins do IRPJ - Série Doutrina Tributária, volume VII. São Paulo: Quartier Lain, 2012.

- RODRIGUES, Silvio. Direito Civil, $17^{\mathrm{a}}$ edição, volume 1. São Paulo: Saraiva, 1987.

- ROPPO, Enzo. O Contrato, tradução de Ana Coimbra e M. Januário C. Gomes. Coimbra: Almedina, 2009.

- ROTHMANN, Gerd Willi. O Princípio da Legalidade Tributária in Direito Tributário - 5 Coletânea. São Paulo: Bushatsky, 1973.

. O “Standard” Jurídico in Doutrinas Essenciais, Direito Civil, Parte Geral, Volume 1, MENDES, Gilmar Ferreira e STOCO, Rui (Org.). São Paulo: Revista dos Tribunais, 2011.

- PRATES, Renato Martins. Interpretação Tributária e a Questão da Evasão Fiscal. Belo Horizonte: Del Rey, 1992. 
- SCAFF, Fernando Facury. Arbitramento e Norma Antielisão: da Estrita Legalidade ao Devido Processo Legal in Revista de Direito Tributário, volume 90. São Paulo: Malheiros, 2000.

. In Dubio Pro Contribuinte e o Voto de Qualidade nos Julgamentos

Administrativos-Tributários in Revista Dialética de Direito Tributário, volume 220. São Paulo: Dialética, 2014.

- SCAFF, Fernando Facury e MAUÉS, Antonio G. Moreira. Justiça Constitucional e Tributação. São Paulo: Dialética, 2005.

- SCHAUER, Frederick. Playing by the Rules, a Philosophical Examination of RuleBased Decision-Making in Law and in Life. Oxford: Clarendon Press, 1993.

- SCHOUERI, Luís Eduardo (coord.). Planejamento Tributário e o "Propósito Negocial”. São Paulo: Quartier Latin, 2010.

- SCHOUERI, Luís Eduardo. Distribuição Disfarçada de Lucros. São Paulo: Dialética, 1996.

. Discriminação de Competências e Competência Residual in Direito

Tributário: Estudos em Homenagem a Brandão Machado. São Paulo: Dialética, 1998.

Fato Gerador da Obrigação Tributária in Direito Tributário -

Homenagem a Alcides Jorge Costa, SCHOUERI, Luís Eduardo (Cood.). São Paulo: Quartier Latin, 2003.

. Normas Tributárias Indutoras e Intervenção Econômica. Rio de Janeiro: Editora Forense, 2005.

. O Desafio do Planejamento Tributário in Planejamento Tributário e

o "Propósito Negocial”, SCHOUERI, Luís Eduardo (coord.). São Paulo: Quartier Latin, 2010.

- Tributário: Estudos em Homenagem a Brandão Machado. São Paulo: Dialética, 1998. Direito Tributário. Editora Saraiva, São Paulo, 2011. Ágio em Reorganizações Societárias (Aspectos Tributários). São Paulo: Dialética, 2012.

- SEIXAS FILHO, Aurélio Pitanga. A Interpretação Econômica no Direito Tributário, a Lei Complementar $n^{\circ}$ 104/2001 e os Limites do Planejamento Tributário in $\mathrm{O}$ Planejamento Tributário e a Lei Complementar 104, ROCHA, Valdir de Oliveira (Coord.). São Paulo: Dialética, 2002. 
- SILVA, Fabiana Carsoni Alves F. da. Direito Tributário e Contabilidade: Independência e Intersecção. A Convivência das duas Ciências in Revista Tributária e de Finanças Públicas, volume 132, BRITO, Edvaldo Pereira de (Coord.). São Paulo: Thomson 2017. Deuters, Disponível também em < http://www.marizsiqueira.com.br/Artigos.html>. Acesso em 27 de março de 2017.

- SILVA, José Afonso da. Curso de Direitos Constitucional Positivo, 30ª edição, revista e atualizada (até a Emenda Constitucional n. 56, de 20.12.2007). São Paulo: Malheiros, 2008 .

- SOUZA, Rubens Gomes de. Compêndio de Legislação Tributária. São Paulo: Resenha Tributária, 1975.

- TABOADA, Carlos Palao. La Aplicación de las Normas Tributarias y la Elusión Fiscal, Colección de Derecho Público y Econômico. Valladolid: Lex Nova S.A., 2009.

- TIPKE, Klaus e LANG, Joachim. Direito Tributário (Steuerrecht), volume I, tradução da $18^{\mathrm{a}}$ edição alemã, totalmente refeita, de Luiz Dória Furquim. Porto Alegre: Sergio Antonio Fabris Ed., 2008.

- TOMÉ, Fabiana Del Padre. A Prova no Direito Tributário, 2a Edição. São Paulo: Noeses, 2008.

. Conhecimento, Verdade e Direito Tributário in Revista de Direito

Tributário, volume 106. São Paulo: Malheiros, 2009.

- TÔRRES, Heleno Taveira. Direito Tributário e Direito Privado: Autonomia Privada, Simulação, Elusão Tributária. São Paulo: Revista dos Tribunais, 2003.

Direito Constitucional Tributário e Segurança Jurídica: Metódica

da Segurança Jurídica do Sistema Constitucional Tributário. São Paulo: Revista dos Tribunais, 2011.

- TORRES, Ricardo Lobo. A Chamada "Interpretação Econômica do Direito Tributário", a Lei Complementar 104 e os Limites Atuais do Planejamento Tributário in O Planejamento Tributário e a Lei Complementar 104, ROCHA, Valdir de Oliveira (Coord.). São Paulo: Dialética, 2002.

Interpretação e Integração da Lei Tributária in Interpretação e Aplicação da Lei Tributária, MACHADO, Hugo de Brito (Coord.). São Paulo: Dialética, 2010. 
O Abuso do Direito no Código Tributário Nacional e no Novo

Código Civil in Direito Tributário e o Novo Código Civil, GRUPENMACHER, Betina Treiger (Coord.). São Paulo: Quartier Latin, 2004. Curso de Direito Financeiro e Tributário. Rio de Janeiro: Renovar, 2006.

Norma Geral Antielisão in Planejamento Tributário, MACHADO, Hugo de Brito (Coord.). São Paulo: Malheiros: ICET, 2016.

- TROIANELli, Gabriel Lacerda. Pode a Prevalência da Substância sobre a Forma ser Invocada pelo Contribuinte? in Revista Dialética de Direito Tributário, volume 96. São Paulo: Dialética, 2003.

- TUDISCO, Flávio. A Causa dos Negócios Jurídicos, a Prevalência da Substância sobre a Forma e o Direito Tributário Brasileiro in Revista de Direito Tributário Atual, volume 22. São Paulo: Dialética, 2008.

- VELlOSO, Andrei Pitten. Conceitos e Competências Tributárias. São Paulo: Dialética, 2005.

- VENOSA, Sílvio de Salvo. Direito Civil - Contratos em Espécie, $7^{\mathrm{a}}$ edição. São Paulo: Editora Atlas, 2007.

- VERÇOSA, Haroldo Malheiros Duclerc. Contratos Mercantis e a Teoria Geral dos Contratos - O Código Civil de 2002 e a Crise do Contrato. São Paulo: Quartier Latin, 2010.

- VILlEGAS, Héctor. Curso de Direito Tributário, tradução de Roque Antonio Carrazza. São Paulo: Revista dos Tribunais, 1980.

- WATTS, Ronald Lampman. Sistemas Federales Comparados. Barcelona: Marcial Pons, 2006.

- XAVIER, Alberto. Os Princípios da Legalidade e da Tipicidade da Tributação. São Paulo: Revista dos Tribunais, 1978.

Tipicidade da Tributação, Simulação e Norma Antielisiva. São

Paulo: Dialética, 2002.

Da Tributação dos Rendimentos Pagos a Titulares de Data Center

Residentes no Exterior in Revista Dialética de Direito Tributário, volume 234. São Paulo: Dialética, 2015.

- XAVIER, Alberto Pinheiro. Conceito e Natureza do Lançamento Tributário. São Paulo: Juriscredi, 1972. 
- YAMASHITA, Douglas; e TIPKE, Klaus. Justiça Fiscal e Princípio da Capacidade Contributiva. São Paulo: Malheiros, 2002.

- ZILVETTI, Fernando e ALELI, André. Planejamento Tributário - Resistência ao Poder de Tributar in Planejamento Tributário, MACHADO, Hugo de Brito (Coord.). São Paulo: Malheiros: ICET, 2016.

- BRASIL. Constituição (1988). Constituição da República Federativa do Brasil. Brasília, DF: Senado, 1988.

- BRASIL. Lei n ${ }^{o} 4.728$, de 14 de julho de 1965. Disciplina o mercado de capitais e estabelece medidas para o seu desenvolvimento. Diário Oficial da União, Brasília, DF, 16 jul. 1965, retificado em 16 ago. 1965.

- BRASIL. Lei n ${ }^{\circ}$ 5.172, de 25 de outubro de 1966. Dispõe sobre o Sistema Tributário Nacional e institui normas gerais de direito tributário aplicáveis à União, Estados e Municípios. Diário Oficial da União, Brasília, DF, 27 out. 1966, retificado em 31 out.. 1966.

- BRASIL. Lei n 5.869, de 11 de janeiro de 1973. Institui o Código de Processo Civil. Diário Oficial da União, Brasília, DF, 17 jan. 1973, republicado em 27 jul. 2006.

- BRASIL. Lei ${ }^{\circ}$ 9.514, de 20 de novembro de 1997. Dispõe sobre o Sistema de Financiamento Imobiliário, institui a alienação fiduciária de coisa imóvel e dá outras providências. Diário Oficial da União, Brasília, DF, 21 nov. 1997, retificado em 24 nov. 1997.

- BRASIL. Lei no 10.406, de 10 de janeiro de 2002. Institui o Código Civil. Diário Oficial da União, Brasília, DF, 11 jan. 2002.

- BRASIL. Lei $n^{\circ} 10.931$, de 2 de agosto de 2004. Dispõe sobre o patrimônio de afetação de incorporações imobiliárias, Letra de Crédito Imobiliário, Cédula de Crédito Imobiliário, Cédula de Crédito Bancário, altera o Decreto-Lei no 911, de 1o de outubro de 1969, as Leis no 4.591, de 16 de dezembro de 1964, no 4.728, de 14 de julho de 1965, e no 10.406, de 10 de janeiro de 2002, e dá outras providências. Diário Oficial da União, Brasília, DF, 03 ago. 2004.

- BRASIL. Lei $n^{\circ} 11.033$, de 21 de dezembro de 2004. Altera a tributação do mercado financeiro e de capitais; institui o Regime Tributário para Incentivo à Modernização e à Ampliação da Estrutura Portuária - REPORTO; altera as Leis nos 10.865, de 30 de abril de 2004, 8.850, de 28 de janeiro de 1994, 8.383, de 30 de dezembro de 1991, 10.522, de 19 de 
julho de 2002, 9.430, de 27 de dezembro de 1996, e 10.925, de 23 de julho de 2004; e dá outras providências. Diário Oficial da União, Brasília, DF, 22 dez. 2004.

- BRASIL. Lei $n^{\circ}$ 11.196, de 21 de novembro de 2005. Institui o Regime Especial de Tributação para a Plataforma de Exportação de Serviços de Tecnologia da Informação REPES, o Regime Especial de Aquisição de Bens de Capital para Empresas Exportadoras RECAP e o Programa de Inclusão Digital; dispõe sobre incentivos fiscais para a inovação tecnológica; altera o Decreto-Lei no 288, de 28 de fevereiro de 1967, o Decreto no 70.235, de 6 de março de 1972, o Decreto-Lei no 2.287, de 23 de julho de 1986, as Leis nos 4.502, de 30 de novembro de 1964, 8.212, de 24 de julho de 1991, 8.245, de 18 de outubro de 1991, 8.387, de 30 de dezembro de 1991, 8.666, de 21 de junho de 1993, 8.981, de 20 de janeiro de 1995, 8.987, de 13 de fevereiro de 1995, 8.989, de 24 de fevereiro de 1995, 9.249, de 26 de dezembro de 1995, 9.250, de 26 de dezembro de 1995, 9.311, de 24 de outubro de 1996, 9.317, de 5 de dezembro de 1996, 9.430, de 27 de dezembro de 1996, 9.718, de 27 de novembro de 1998, 10.336, de 19 de dezembro de 2001, 10.438, de 26 de abril de 2002, 10.485, de 3 de julho de 2002, 10.637, de 30 de dezembro de 2002, 10.755, de 3 de novembro de 2003, 10.833, de 29 de dezembro de 2003, 10.865, de 30 de abril de 2004, 10.925, de 23 de julho de 2004, 10.931, de 2 de agosto de 2004, 11.033, de 21 de dezembro de 2004, 11.051, de 29 de dezembro de 2004, 11.053, de 29 de dezembro de 2004, 11.101, de 9 de fevereiro de 2005, 11.128, de 28 de junho de 2005, e a Medida Provisória no 2.199-14, de 24 de agosto de 2001; revoga a Lei no 8.661, de 2 de junho de 1993, e dispositivos das Leis nos 8.668, de 25 de junho de 1993, 8.981, de 20 de janeiro de 1995, 10.637, de 30 de dezembro de 2002, 10.755, de 3 de novembro de 2003, 10.865, de 30 de abril de 2004, 10.931, de 2 de agosto de 2004, e da Medida Provisória no 2.158-35, de 24 de agosto de 2001; e dá outras providências. Diário Oficial da União, Brasília, DF, 22 nov. 2005.

- BRASIL. Lei ${ }^{\circ} 11.312$, de 27 de junho de 2006. Reduz a zero as alíquotas do imposto de renda e da Contribuição Provisória sobre Movimentação ou Transmissão de Valores e de Créditos e Direitos de Natureza Financeira - CPMF nos casos que especifica; altera a Lei no 9.311, de 24 de outubro de 1996; e dá outras providências. Diário Oficial da União, Brasília, DF, 28 jun. 2006.

- BRASIL. Lei n ${ }^{\circ}$ 11.418, de 19 de dezembro de 2006. Acrescenta à Lei no 5.869, de 11 de janeiro de 1973 - Código de Processo Civil, dispositivos que regulamentam o $§ 3^{\circ}$ do art. 102 da Constituição Federal. Diário Oficial da União, Brasília, DF, 20 dez. 2006. 
- BRASIL. Lei no 11.672, de 8 de maio de 2008. Acresce o art. 543-C à Lei no 5.869, de 11 de janeiro de 1973 - Código de Processo Civil, estabelecendo o procedimento para o julgamento de recursos repetitivos no âmbito do Superior Tribunal de Justiça. Diário Oficial da União, DF, 9 mai. 2008.

- BRASIL. Lei no 13.105, de 16 de março de 2015. Código de Processo Civil Diário Oficial da União, Brasília, DF, 17 mar. 2015.

- BRASIL. Medida Provisória no 66, de 29 de agosto de 2002. Dispõe sobre a não cumulatividade na cobrança da contribuição para os Programas de Integração Social (PIS) e de Formação do Patrimônio do Servidor Público (Pasep), nos casos que especifica; sobre os procedimentos para desconsideração de atos ou negócios jurídicos, para fins tributários; sobre o pagamento e o parcelamento de débitos tributários federais, a compensação de créditos fiscais, a declaração de inaptidão de inscrição de pessoas jurídicas, a legislação aduaneira, e dá outras providências. Diário Oficial da União, Brasília, DF, 30 de ago. 2002.

- BRASIL. Medida Provisória no 685, de 21 de julho de 2015. Institui o Programa de Redução de Litígios Tributários - PRORELIT, cria a obrigação de informar à administração tributária federal as operações e atos ou negócios jurídicos que acarretem supressão, redução ou diferimento de tributo e autoriza o Poder Executivo federal a atualizar monetariamente o valor das taxas que indica. Diário Oficial da União, Brasília, DF, 22 de jul. de 2015.

- RECEITA FEDERAL DO BRASIL. Instrução Normativa $n^{\circ}$ 1.585, de 31 de agosto, 2015. Dispõe sobre o imposto sobre a renda incidente sobre os rendimentos e ganhos líquidos auferidos nos mercados financeiro e de capitais. Diário Oficial da União, Brasília, DF, 02 de set. de 2015.- SÃO PAULO (Município). Parecer Normativo Secretaria da Fazenda $n^{\circ}$ 02, de 26 de abril de 2016. Incidência do Imposto sobre Serviços de qualquer natureza - ISS nos serviços desenvolvidos no Brasil, cujo resultado aqui se verifique. Disponível em < http://www.prefeitura.sp.gov.br/cidade/upload/PN-SF-022016_1461844434.pdf>, consulta em 15 de julho de 2016.

- SECRETARIA DA RECEITA FEDERAL DO BRASIL. Instrução Normativa nº 599, de 28 de dezembro, 2005. Dispõe sobre os arts. 38, 39 e 40 da Lei $n^{\circ} 11.196$, de 21 de novembro de 2005, relativamente ao Imposto de Renda incidente sobre ganhos de capital das pessoas físicas. Diário Oficial da União, Brasília, DF, 30 de dez. de 2005. 
- SECRETARIA MUNICIPAL DE FINANÇAS E DESENVOLVIMENTO ECONÔMICO DA PREFEITURA DE SÃO PAULO. Parecer Normativo SF nº 02, de 26 de abril de 2016. Incidência do Imposto sobre Serviços de qualquer natureza - ISS nos serviços desenvolvidos no Brasil, cujo resultado aqui se verifique. Diário Oficial do Município de São Paulo, São Paulo, SP, 27 de abr. de 2016.

- SECRETARIA MUNICIPAL DE FINANÇAS E DESENVOLVIMENTO ECONÔMICO DA PREFEITURA DE SÃO PAULO. Parecer Normativo SF nº 04, de 09 de novembro de 2016. Incidência do Imposto sobre Serviços de qualquer natureza - ISS nos serviços desenvolvidos no Brasil, cujo resultado aqui se verifique. Diário Oficial do Município de São Paulo, São Paulo, SP, 10 de nov. de 2016. 